\title{
Sustainability and Contemporary Urbanism in Brazil
}

VICENTE DEL RIO

Vicente del Rio, PhD.

is a professor at $\mathrm{Cal}$

Poly's City and Regional

Planning Department.

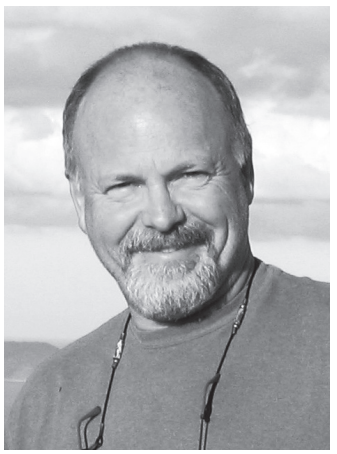

This article is a discussion of sustainability and contemporary Brazilian urbanism. Moving away from the modernist approach which was very destructive of existing contexts, urbanism in Brazil is now pluralistic, participatory, and contextual. This paper reflects in part the contents of Vicente del Rio's and William Siembieda's new book Contemporary Urbanism in Brazil: Beyond Brasilia.

Sustainability is a subjective and complex concept, which has been amply utilized, but rarely, without a clear definition. On the one hand, definitions are not usually dependent on environmental performance, which has typically been the case when reflecting (not sure if reflecting" is the best word choice) desired levels of environmental quality such as air and water quality. On the other hand, the idea of sustainability seems to be suffering from having become fashionable and popular; although constantly used in many contexts, sustainability means different things to different people -and these meanings are deeply engraved in the political objectives of discourses. When we try to understand sustainability as a holistic concept, and particularly when we try to apply such a concept on an urban setting and relate it to development and urbanism, things get much more complicated.

This is certainly the case in Brazil where for a long time economic growth has been a national priority and where, historically, the environment has been looked upon from a traditional ecological perspective. Despite the expansion of democracy and the political advances of the last decade that have been fundamental to a move towards more socially equitable cities, environmental policies are still disconnected from other urban development policies - what is particularly true at the national and state level. While at the local municipal level, new visions of the role of urbanism, the recent master planning processes and wider political participation are helping to advance an urban development that is certainly much more sustainable in political, social, economic, and cultural terms. I am being specific about the types of sustainability here, because of the unfortunate disconnect between physical-land use and environmental planning processes.

According to Curwell et al (2005), many of the intentions of sustainable urban development are released through design and urbanism, and we have chosen some contemporary projects to illustrate this relationship in Brazil. After a brief discussion on sustainability and recent advances in urban planning and policies, this paper will identify the current trends in urbanism and describe some of the most visible and exemplary urban projects. Although these trends and projects reflect Brazil's ties with its post-colonial past, they also reveal the efforts towards building more socially just and sustainable city.

\section{Sustainability and Urbanism in Brazil}

The concept of sustainability in Brazil is still intertwined with the environmental question and the conservation of natural resources, such as the Amazon forest. In the late eighties, after the country's return to democracy, there was strong international and national public opinion against the constant aggressions to the Amazon forest and the perils of climatic change, and this forced the Brazilian government to move towards new environmental policies (Ferreira, 1998). Until then, particularly during the military regime, the needs of "national security" would always be above sustainable development strategies (Ferreira, 1998). In 1986 a federal resolution instituted the need for environmental impact 
review and approval for certain types of development; in 1989 the IBAMA (Brazilian Institute for the Environment and Natural Resources) was created, and the Ministry of the Environment in 1990. Another example of Brazil's efforts to change its international image through the realization of the 1992 United Nations World Conference on Development and the Environment (Earth Summit) in Rio de Janeiro. During this important venture, Brazil was a key participant in a new understanding that policies need to move away from both irresponsible development and conservationism devoid of socio-economic implications. This view was decisive in the creation of Agenda 21 -a key document for the implementation of the notion of sustainability. Above all, the Earth Summit was fundamental in popularizing the idea of a sustainable development and in influencing a change in market demands, in strengthening non-governmental agencies, and in encouraging the spontaneous implementation of such ideas by private corporations who wanted to better their images and to meet the new markets.

However, environmental policy in Brazil is far from being considered a social or a developmental policy. It is weakly related -if related at all- to other public policies, and the environmental question is still largely understood from a traditional ecological and conservationist perspective (Ferreira 1998; Magrini 2008). This lack of relationship between environmental and the rest of public policies is particularly strong at the federal and state levels. For instance, although the 1988 National Constitution has chapters dedicated to urban development and to the environment -which express important gains by the social forces behind the new constitution- the fact that they appear in different chapters reveal a lack of understanding of the needed relationship between the two concepts. The creation, in 2003, of a Ministry of the Cities in parallel to the Ministry of the Environment is another evident expression of the lack of integration and of ideological and political conflicts. Plus, there are other ministries and federal agencies' which policies and programs actions have environmental impacts but are not necessarily congruent to environmental concerns.

Magrini (2008) noted that the only major instrument of national environmental policy that is based on a wide notion of development is the 1997 Water Resources national law. Based on an integrated vision of sustainability, this law defines water basins as units for regional environmental planning and sets regulatory instruments for such. However, such planning and resulting actions depend on the association of the municipalities within the water basins and on the integration of their plans, policies, and actions -still a complex political endeavor. This seems to be an exception to the rule that most policies and environmental instruments in Brazil are non-spatial; they do not relate to any territory in particular, and less to the normal processes of urban and land use planning. However, in the last decades, there have been significant advances in the environmental arena, particularly towards different forms of sustainable urbanism in major cities.

\section{A Preface for Contemporary Urbanism}

Brazil is the largest country and has the largest population, land area, and the highest economic standing in Latin America. Over 80 percent of Brazil's population lives in urban areas. From all cities in Latin America, Brazilian cities are those that exhibit the most social and physical innovation and dynamics in designing the urban realm. After the disruption of the modernist paradigm, the demythication of the Brasilia experience, and the re-democratization of the country in the 1980's, Brazil was eager for new models of urban development and urban form making.

On the one side of the spectrum, social movements pushed toward a new social order and to solutions that are closer to the Brazilian social and cultural heritage. On the other side of the spectrum, globalization and market forces dragged society towards an "entrepreneurial" and fragmented city of shopping centers, gated communities, private enclaves, and trendy and irrelevant architectural imagery. Not unlike other Latin American countries, this duality is clearly expressed in the urban 
landscape and it reflects a constant tension between opposite realms: global-local, private-public, individual-collective, and poor-wealthy.

After the military left power and the country returned to a democratic state in 1985, Congress passed a new national constitution in 1988. The constitution had a strong impact in regards to urban development, defining the municipality as having political, financial, and economic autonomy-a novelty in Latin America. This "municipalization" of the country's power structure led states to change their state constitutions and municipalities to elaborate new Leis Orgânicas-the legal body that govern their functioning and organization. The national constitution also introduced the concept of the "social role of urban property and of the city" and recognized the need for a more socially inclusive urban development. It empowers cities to play an active role in land use development control, and ideologically it perceives the city as a locus for the redistribution of wealth and for the re-democratization of society.

One of the constitution's chapters was dedicated to the environment while another to urban development -which as we observed above reflects an epistemological misunderstanding about their necessary integration. The chapter "urban policy" determines that cities with 20,000 residents or more need to have a master plan. It also determines that the social role of a property is above the owner's rights of use, that an urban squatter has the right to his or her land after five years of undisputed use, and that cities can mandate the use of vacant land either directly or through the progressive increase of taxes. The chapter on "environmental policy" determines that all people have the right to a balanced environment -which is considered for collective use and fundamental for the quality of life- and lists ways that the public may use its power may to guarantee it. This determines that hostility toward the environment must be penalized, and identifies the country's major natural habitats as of national interest. Although there is no mention of the expression "sustainable development" in the constitution, it is inherently contained in the identification at the local level as the most important in conducting urban development and control, and in the recognition of the importance of an ecologically balanced development.

Brazil's most recent significant attempt at institutionalizing urbanism (including urban design) as a social tool and a possible instrument for sustainability occurred in 2001 with the Estatuto da Cidade (Statute of the City). Resulting from years of national debates on the necessity of an urban reform and on how to detail and implement the principles that had been established in the national constitution, the city statute provided municipalities with new powers to control development (instruments such as transfer development rights, taxation flexibility, etc) and to engage in projects that meet local needs, and implement components of the sustainability paradigm. The Statute also introduced the notion of neighborhood impact and the need for neighborhood studies and approval for certain types of projects -a process to be defined by each city, which opens up a debate at the local political arena.

Thus, the political developments in the last twenty years: the strengthening of democracy, the increase of public participation, and the environmental question has experimented with important advances at the local level. Urban policies in several cities -particularly in those with stronger planning and environmental systems- incorporate a wider and more integrated understanding of the environment and an inherent understanding of sustainable development. Both the Constitution and the City Statute have contributed significantly to the environmental "cause" when calling for a better and socially just city since it is a perspective that incorporates the notion of a development that is socially sustainable. These dynamic changes in the political, economic and demographic makeup of Brazil in the last twenty years have resulted in the emergence of an interesting contemporary urbanism.

From the practice of urbanism in the past two decades three major trends may be identified in Brazil. The first is Late Modernism, representing projects that adapt modernist concepts to new realities, although many still tend to reproduce some of the common mistakes of the old modernist model. 
Secondly, Revitalization, or the reutilization of the existing city and built environment, in which projects preserve the historic and cultural values while still making way to new practices. And thirdly, Social Inclusion, which represent projects that make use of the public realm as a locus for socialization and social equity. These trends represent a move towards more sustainable cities, if not from a traditional ecological perspective then from social, economical, and political perspectives. Next, I will briefly discuss some of these projects.

\section{Trend 1: Late Modernism}

Modernism penetrated deep in Brazilian culture, planning and design, and its inherent positivist expectations still dominate most thinking, particularly the notions that urban development is intrinsically good, and that there is a rational order to things (Harvey 1990; Lara 2008). The evolution of urbanism in Brazil helped popularize the modernist notions of urban quality, which today are still important for urban development and public expectations. The late-modernism trend represents how alive and well modernist thinking is in Brazil's urbanism, and how it is still utilized to control the city's form and function towards an idealized model.

Fundamentally, plans and projects identified with this trend share a belief that if the government would control the market and the urban development process, the results would guarantee the common public good. Also, as in modernism, late-modernism practices are usually closed to public participation processes as its paradigm is based on governmental control, and in planners paternalistically deciding what is good for the community, overseeing and directing the behavior of the private sector. Like modernism, late-modernism shows an inherent difficulty towards sustainable development, since it is based on a closed notion of progress and on products defined beforehand, not in processes democratically defined that would characterize a holistic vision of sustainability.

Two "new towns" help us understand the impact of late modernism on contemporary cities. The modernist capital of Brasilia, more that any other Brazilian city, follows a dual process of urban development. While its modernist design has several well-known problems that only worsen over time, even the qualities of its design suffer from progressive deterioration albeit the government's efforts in preserving the original project area (Pilot Plan). The well known classic modernism that made Brasilia such a strong cultural artifact and influenced so many planning efforts throughout Brazil, suffer from strong separation of functions and an automobile-oriented design -both diametrically opposed to any notion of sustainability other than the political and symbolic (Kohlsdorf, Kohlsdorf \& Holanda 2008). Although most residents of Brasilia recognize its symbolic and aesthetic qualities, Kohlsdorf, Kohlsdorf \& Holanda recognize and experience several difficulties in their use of the city structure, as did Holston in his landmark book on Brasilia's modernism (Holston, 1989). Late modernism is engraved in the new districts, and planned by the government to receive the growth of Brasilia, which follow the same design mistakes of classic modernism.

The planning and design of Brasilia also reveals a strong duality with the city's surroundings, where settlements that predate the new capital together with satellite towns and irregular settlements (favelas) have a much large population than Brasilia itself, and show strong social and economic vitality (Fig. 1). As urban places, they are much more self-sustained than the capital, and they certainly permit the region of Brasilia to be socially, economically, and culturally sustainable as a whole.

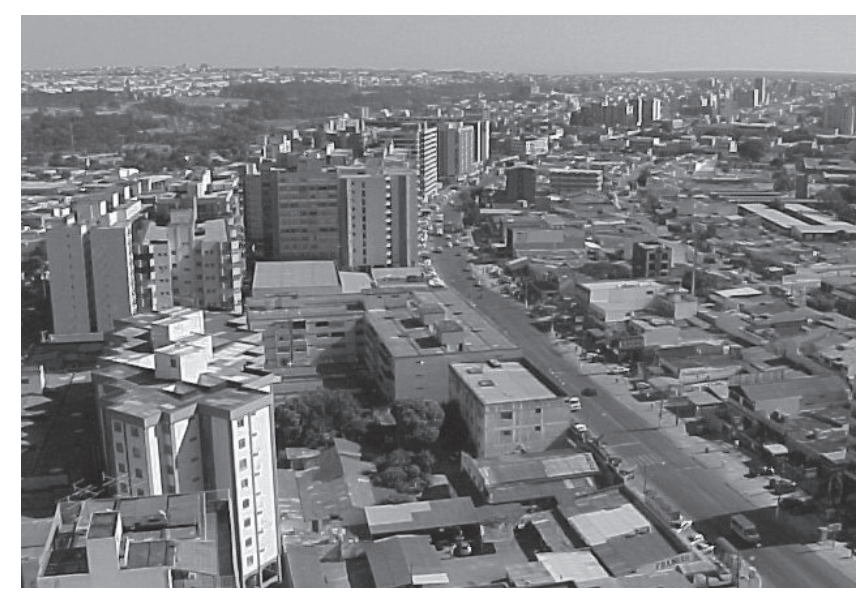

\section{Figure 1}

Taguatinga, one of Brasilia's irregular "satellite towns" from the early 1970s has a life of its own and is not dependent on the capital. (photo Frederico Holanda) 


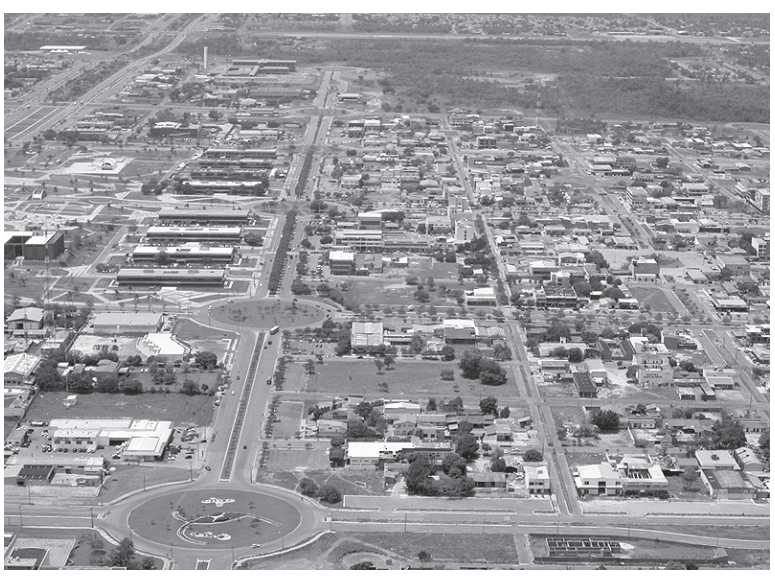

Figure 2

Aerial view of the center of Palmas, new capital of the state of Tocantins. A modernist project that has been developed as a typical frontier town. (photo Newton Paniago)

Figure 3

Buildings in the Cultural Corridor Project, Rio de Janeiro's historic downtown. The middle building was built in 1986 according to the area's specific design guidelines. (photo Denise Alcantara)

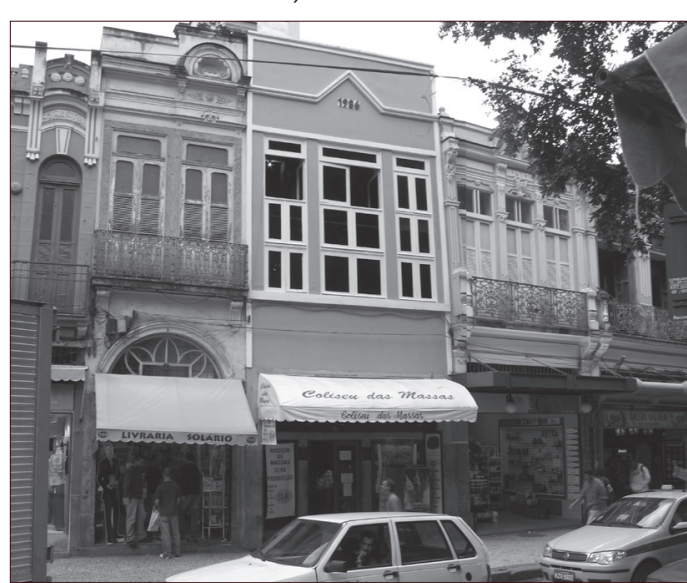
development approaches.

\section{Trend 2: Revitalization}

The idea behind the building of Palmas in 1990 as the capital of Tocantins, a new state in central Brazil, was to apply the Brasilia model of regional development (Trindade 2008). In this respect, like Brasilia, Palmas was successful as it generated intense development in a backward region. The town's population went from 86,116 in 1996 to 160,000 in 2003 -almost $15 \%$ of the total population in the state of Tocantins. Extensive infrastructure investments including a dam and water reservoir, a regional highway, a railway, and an airport were built to connect Palmas to the rest of the state, and the city fulfilled its mission of integrating the region and creating a new society in the midst of the cerrado (savannah, an arid geography).

The original concept plan urged for an environmentally sensitive and sustainable design that preserved the natural environment. Inspired in modernist Brasilia and Milton Keynes, the design was based on a macro-grid that defined large amounts of open spaces, preservation along bodies of water, and provided the lakefront with abundant recreation and park areas. The road network and infrastructure would define sectors of 105 acres hectares where private developers would be left with great flexibility in deciding the internal land uses and urban design, what in theory, would encourage sustainable

Utopia, however, was trampled by reality as the state government acted as land developer and the openness of the original design induced speculative development (Fig. 2). Planning in Palmas was confused with subdividing land and selling lots, which was constrained only by an obsolete Euclidian zoning legislation. Today, dense commercial strips are served by wide roads where large distances and vehicular traffic impede the flow of pedestrians. The amount of paving in the wide streets and sidewalks, barren modernist plazas, and intense development induce much higher temperatures in the summer. The large open areas: parks and artificial beaches along the lakefront are the only elements that make Palmas different from other frontier towns. Once again, like Brasilia, although the resulting urbanism in Palmas cannot be said to be an example of sustainability, particularly due to the rapid and speculative growth process, the town has successfully induced regional sustainability through economic and social development in the interior of the new state.

By the mid 1980s, the majority of the large cities in Brazil had realized they should direct planning and design toward the redevelopment of their downtowns. Vacant, deteriorating or underutilized buildings, "planning blight," antiquated zoning and regulations, and over ambitious road projects were some of the problems to be faced. Unlike North-American cities, most of these areas were still being heavily utilized by a large amount of the population, particularly riders of public transportation that had to use central stations. The historic and cultural patrimony had to be respected for legal, symbolic, and political reasons, thus introducing a new perspective of sustainability. Over the past two decades, several revitalization projects are changing many areas in Brazil's major cities, most with a cultural and recreational bias; good examples can be found in the cities such as Rio, Salvador, São Paulo, Recife, Porto Alegre, and Belem. To move towards a sustainable urban development, these projects had to focus on shared decision-making and on the use of publicprivate partnerships. 


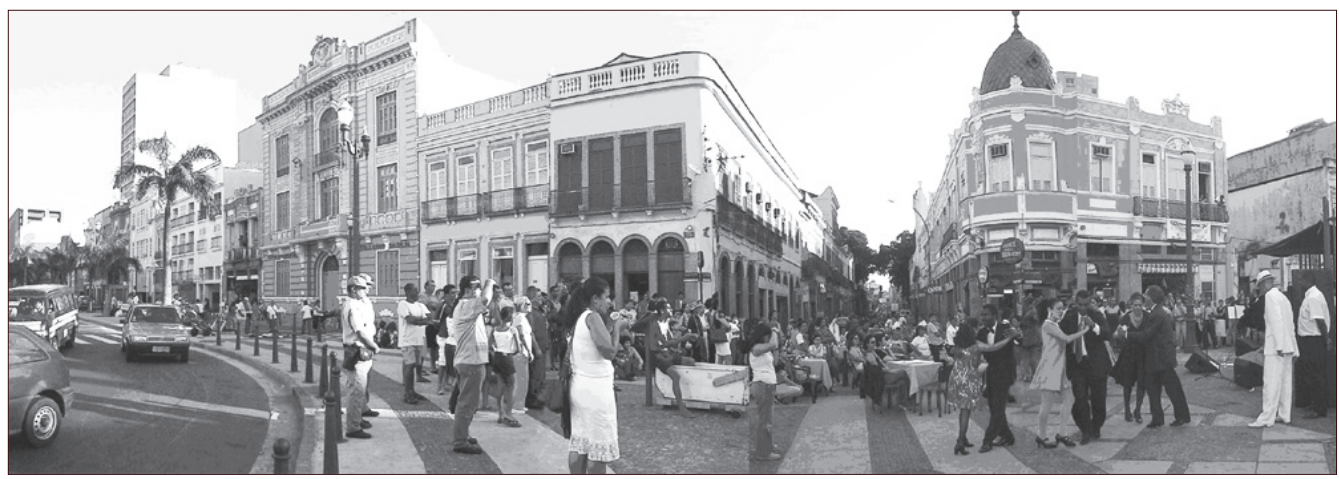

The most important of such projects is the Cultural Corridor Project in Rio de Janeiro, Conceived in 1982; it was the first inner-city revitalization program in Brazil (del Rio \& Alcantara 2008). Both a pioneering and an integrative effort, the project cancelled the modernist zoning and old renovation projects in the downtown. It encouraged the population to preserve the historical and cultural architectural heritage, promoted social and economic revitalization, and renovated the cultural role of the city center. The project is implemented through special design guidelines, tax abatements, specific cultural programs, and street renovation (Fig. 3). In 2004 the Cultural Corridor included more than 3,000 buildings, $75 \%$ of which had been partially restored and 900 had been totally renovated. In addition, the area received more than 25 new cultural centers, theaters and museums, and various street beautification projects. Last year, the first new residential complex for more than forty years was inaugurated and now contributes to add new life to the downtown. This successful urbanism is sustainable in many aspects, and it harmonizes architectural to social, cultural, and economic regeneration (Fig. 4).

The success of the Cultural Corridor Project and its sustainability model inspired other Brazilian cities in their quest for preserving historic architecture and revitalizing central areas. One of these cities is Salvador, Brazil's first colonial capital which historic core contains one of the most important collections of colonial buildings and churches in Latin America. The Pelourinho district, an area of the historic core around the pelourinho (or wiping post, where slaves and criminals were punished), is a UNESCO's World Heritage Site and was the object of an ambitious large scale public project to fulfill its strategic role in national and international tourism (Fernandes \& Gomes 2008). A controversial project from the early nineties renovated the area and achieved a significant increase in cultural gentrification and tourism (Fig. 5).

Although it evicted most of its original population, the project managed to reposition a place that was seriously deteriorated by making it safer and more attractive for locals and tourists, revitalized local cultural practices and the economy, and created new conditions for a proper maintenance of the historical architecture. In recent years, the local dynamics are changing again, and the city is ensuring a gradual return of residents and some of the traditional social practices.

Even the private sector is promoting an urbanism of revitalization, like in the DC Navegantes; a popular outlet shopping center in Porto Alegre, Rio Grande do Sul. This project was totally planned and developed by the private sector that invested in the reutilization of a brownfield (Castello 2008). Different from post-modernist practices, which are based on
Figure 4

A street outside the area of the Cultural Corridor, was impacted and is now revitalized, with renovated public spaces, busy shops, and several street events. (photo Denise Alcantara)

\section{Figure 5}

The Pelourinho area in Salvador after renovation has been revitalized with tourist oriented uses and events. (photo Griselda Kluppel)

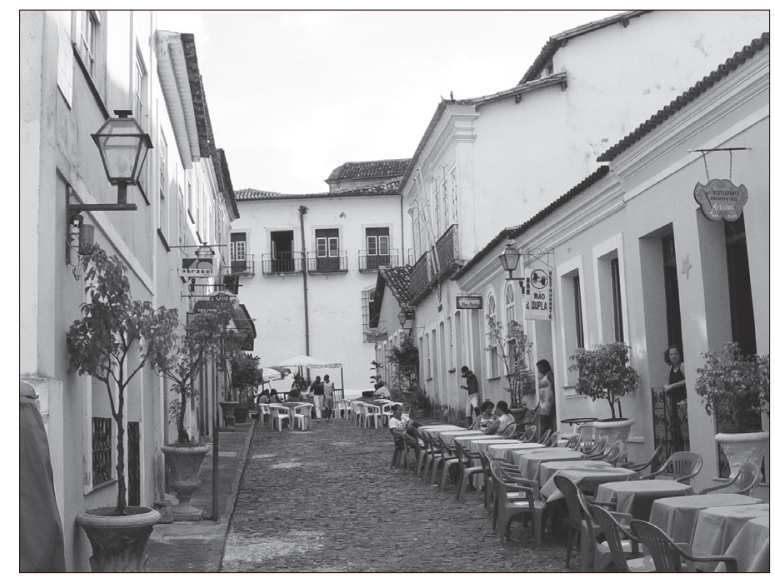




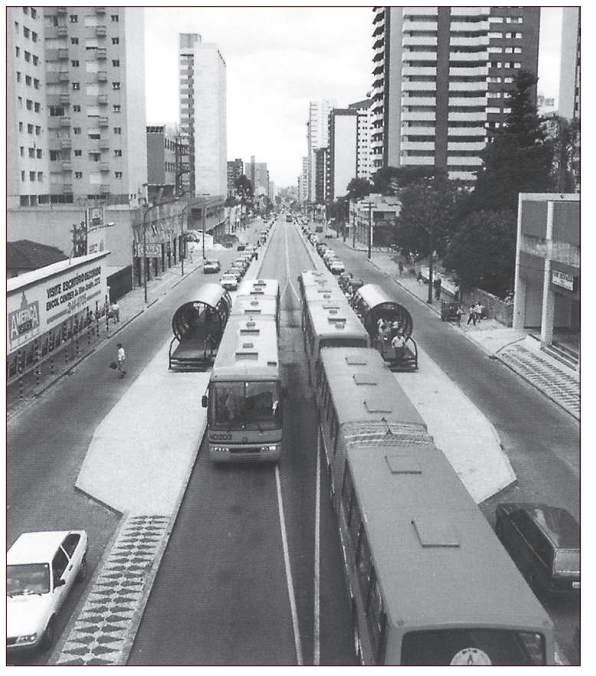

Figure 6

The dedicated express lanes for the rapid bi-articuled buses run along mixed-use dense corridors in Curitiba. (photo source IPPUC)

Figure 7

Projeto Rio Cidade renovated commercial corridors in Rio. A view of the project for Meier. (photo Aerocolor)

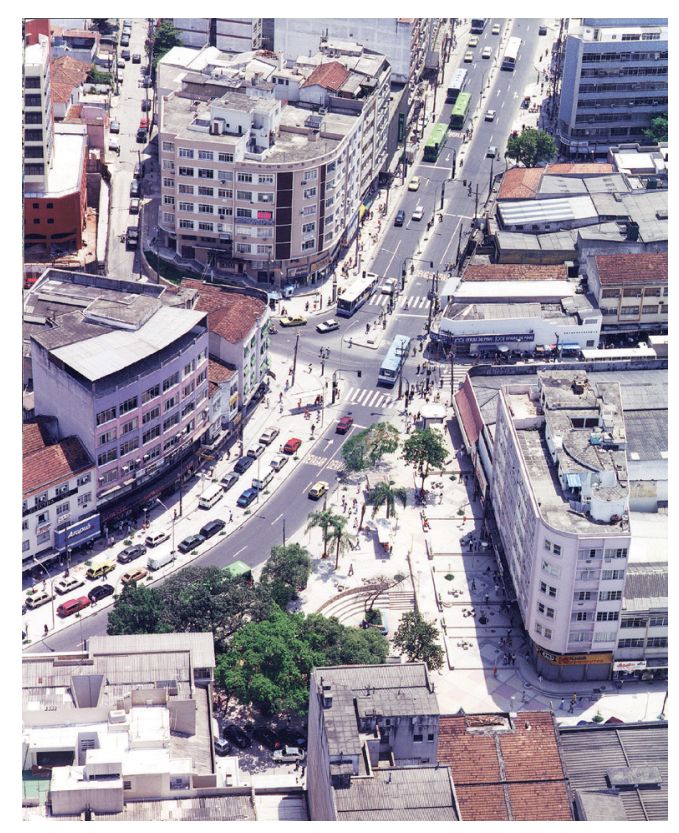

false identities, this project explored its own historical industrial architecture, the centrality of the area, and its accessibility by public transportation. Dozens of shops and eateries in recycled industrial buildings, new additions, interesting landscaping, and areas for public events generate an attractive mix. The DC Navegantes mall was expanded from its original site, and other private developers responded by converting other buildings and implementing more attractions that continue to revitalize the surrounding areas.

\section{Trend 3: Social Inclusion}

One of the most important trends in Brazilian urbanism is the move towards a sustainable social inclusion: an opposite outcome of most social and economic models of globalization. Urbanism plays an important part in the re-democratization of Brazil in guaranteeing the social function of the public realm, and as a tool in responding to the social function of city. Citizens and political parties realized that the quality of public spaces and services are major aspects for full citizenship. Public urbanism moved towards generating a socially sustainable city, recuperating the city as a pluralist environment, while seeking to extend social and cultural amenities to larger groups. These efforts are particularly clear through the experiences in Curitiba, but also in other cities through the renovation of public spaces and the upgrading of favelas (shanty towns; squatter settlements).

The successful story of Curitiba is well known (Hawken, Lovins \& Lovins 1999; Schwartz 2003; Irazabal 2005 \& 2008). Since the 1970s the city has been successful in implementing a planning process and urban design solutions that have served as national and international examples: an efficient public transportation system that is integrated to land use planning, a lively pedestrian precinct in the historical core, a city-wide system of bike trails and numerous new parks, efficient garbage collection in shanty towns, and other innovations (Fig. 6). Curitiba now faces problems generated by its own successes: population growth attracted by its quality of life, a needy (Not sure if "needy" is the best word choice) metropolitan area, and a population that is used to relying on paternalistic public planning.

An important effort in urbanism toward sustainability and social inclusion is Projeto Rio Cidade, a citywide program for remodeling public spaces in Rio de Janeiro's commercial cores started in 1993 (del Rio 2008). These areas were deteriorated and had been taken over by street vendors and other forms of illegal practices. Through public competitions, several private firms were hired to redesign the public spaces through new streetscaping, new furniture, public lighting, and the reorganization of vehicular circulation (Fig. 7). Through very different designs for different neighborhoods, Rio Cidade helped to strengthen local identities while providing for a more comfortable use of the public realm. Projects attracted new private investment, revitalized retail, and contributed to the transformation of the city image as a whole.

Another important example is Favela Bairro, an innovative program by the city of Rio de Janeiro to upgrade favelas (squatter settlements) (Brakarz 2002; Duarte and Magalhaes 2008). This project considered environmental upgrading and security of tenure as fundamental steps toward sustainability, a community's development and integration to the city, and eventually full citizenship. As in the case of Rio Cidade, private firms were hired through public competitions to design for small and medium sized favelas throughout the city. Physical 
improvements included installation of storm drainage, sewage, water pipes, public lighting, vehicular and pedestrian accesses, playgrounds and recreation areas (Fig. 8).

Community development included educational and income generation projects such professional training, work cooperatives, and hiring residents for trash collection and reforestation. Community buildings would be occasionally built by the program, such as daycare centers and new housing units for families evicted from their original homes by the project. The Favela Bairro program is an excellent example of social and environmental sustainability, and benefited more than 500,000 people in 143 favelas througout Rio de Janeiro.

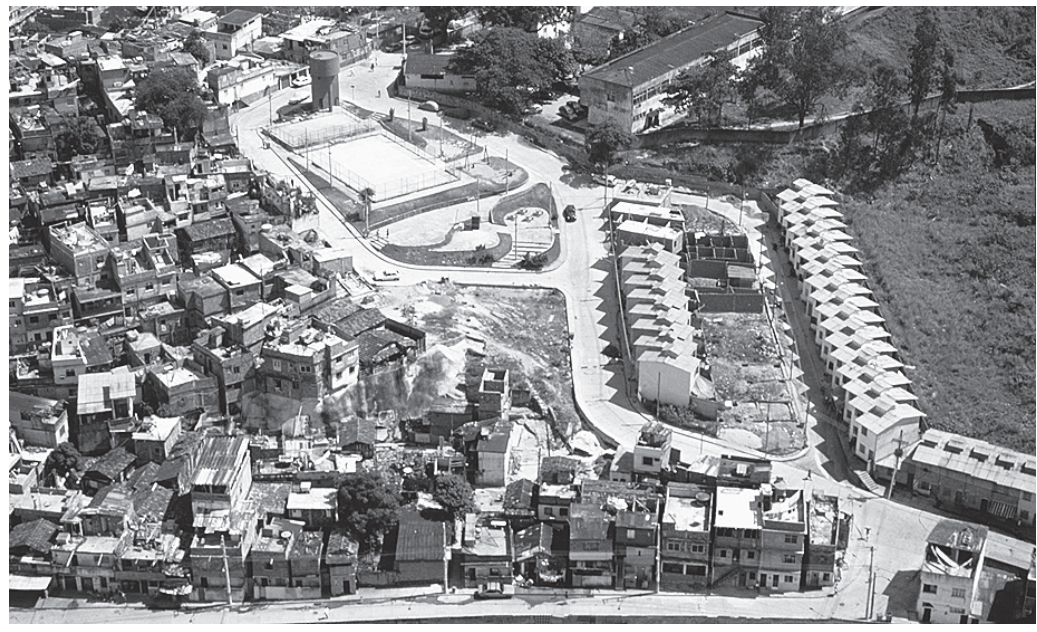

Figure 8

The Favela Bairro upgraded squatter settlements in Rio. A view of Favela Ladeira dos Funcionarios, with new parks and residential units. (photo Fabio Costa Silva) and in a better quality of the urban realm. New urban projects have been generating places that are more livable, attractive, and responsive to the social and economic reality of the communities they are serving. The public realm is being redefined through various experiments at the local level.

Contemporary urbanism in Brazil have moved away from a model that was frozen inside a modernist paradigm, to one that respects different approaches in a quest for more sustainable cities in social, political, and economic terms. Different from modernism which relied on centralized control and determined rigid models of what and how a city should be, contemporary Brazilian urbanism may be considered postmodern in the sense that it incorporates different visions of quality of the public realm, and includes different stakeholders participating in its creation and maintenance.

Although environmental, economic, and urban policies still have to be more decisively integrated, and environmental planning has to rely more on specific spatial and social expressions, the practices of urbanism in Brazil have advanced towards Godschalk's sustainability prism model in which all vertices are in a constant state of conflict but which results in a balanced environment having livability on the top (Fig. 9) (Godschalk 2004). While the ecological vertex is still to be more and better cared for, Brazilian cities have advanced significantly towards the equity, the economic, and the livability vertices. Hopefully, with the advance of democracy and public participation, in the next few years, we will see a more balanced and sustainable development model in Brazil, and particularly a better integration between environmental planning and urbanism.

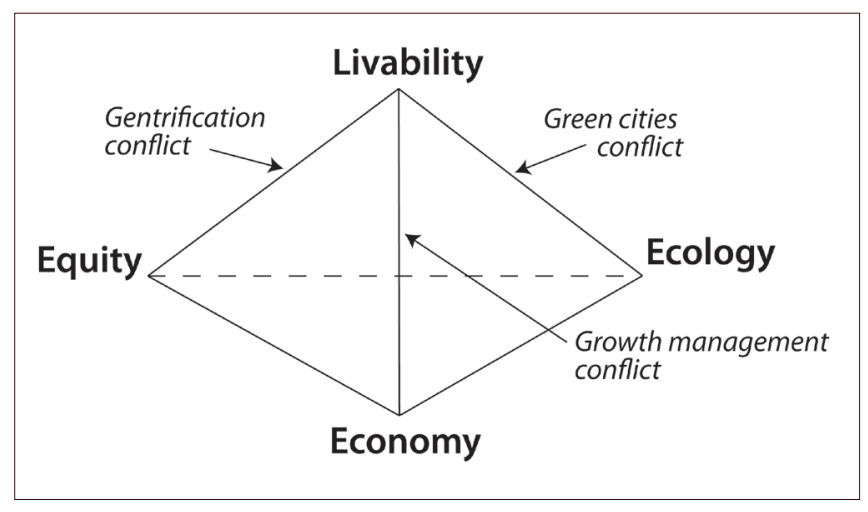

\section{Figure 9}

The sustainability prism model by Godschalk puts livability on the top over a base of equity, ecology, and economy, and in a constant equilibrium resulting from the permanent conflicts between these values (from Godschalk, 2004). 


\section{References}

Brakarz, Jose. 2002. Cities for All: Recent Experiences with Neighborhood Upgrading Programs. Washington DC: Inter-American Development Bank.

Castello, Lineu. 2009. Redesigning Brownfields in Porto Alegre. In del Rio, V. \& Siembieda, W. (2009).

Curwell, Steven, Deakin, Martin \& Symes, Martin. 2005. Sustainable Urban Development: The Framework and Protocols for Environmental Assessment. Volume 1. Oxford, England: Routledge.

del Rio, Vicente. 2009. Reclaiming City Image and Street Livability: Projeto Rio Cidade, Rio de Janeiro. In del Rio, V. \& Siembieda, W. (2009).

del Rio, Vicente \& Alcantara. 2009. Cultural Corridor: Preservation and Revitalization in Downtown Rio de Janeiro. In del Rio, V. \& Siembieda, W. (2009)

del Rio, Vicente \& Siembieda, William; eds. 2009. Contemporary Urbanism in Brazil: Beyond Brasilia. Gainesville: University Press of Florida.

Duarte, Cristiane \& Magalhaes, Fernanda. 2009. Upgrading Squatter Settlements into City Neighborhoods: The Favela Bairro Program in Rio de Janeiro. In del Rio, V. \& Siembieda, W. (2009).

Fernandes, Edesio. 2007. Constructing the Right to the City in Brazil. Social Legal Studies 16(2): 20119.

Fernández, Ana \& Gomes, Marco Antonio Filgueiras. 2009. Revisiting the Pelourinho: Preservation, Cultural Heritage, and Place Making. In del Rio, V. \& Siembieda, W. (2009)

Ferreira, Leila da Costa. 1998. A Questao Ambiental: Sustentabilidade e Politicas Publicas no Brasil. Sao Paulo: Boitempo Editorial.

Godschalk, David. 2004. Land use planning challenges: Coping with conflicts in sustainable development and livability community visions. Journal of the American Planning Association 70 (1): 5-13.

Harvey, David. 1990. The Condition of Postmodernity. Cambridge MA: Blackwell.

Hawken, P., Lovins, A. \& Lovins, H. 1999. Natural Capitalism: Creating the Next Revolution. Boston: Little, Brown \& Co.

Holston, James. 1989. The Modernist City: An Anthropological Critique of Brasilia. Chicago: The University of Chicago Press.

Irazabal, Clara. 2005. City Making ad Urban Governance in the Americas - Curitiba and Portland. Aldershot, England: Ashgate

Irazabal, Clara. 2009. Urban Design, Planning, and the Politics of Development in Curitiba. In del Rio, V. \& Siembieda, W. (2009).

Kohlsdorf, Maria Elaine, Kohlsdorf, Gunter \& Holanda, Frederico. 2009. Brasilia: Permanence and Transformations. In del Rio, V. \& Siembieda, W. (2009).

Lara, Fernando, 2008. The Rise of Popular Modernist Architecture in Brazil. Gainesville: University Press of Florida.

Magrini, Alessandra. 2008. Personal interview. October 3, 2008.

Schwartz, Hugh. 2003. Urban Renewal, Municipal Revitalization: The Case of Curitiba, Brazil. Published by the author.

Trindade, Dirceu. 2009. Challenges for New Town Design in a Frontier Region: Palmas. In del Rio, V. \& Siembieda, W. (2009)

Wilheim, Jorge. 2001. Metropoles e Faroeste no Seculo XXI. In Sachs, Ignacy, Wilheim, Jorge \& Pinheiro, Paulo Sergio (eds.) Brasil: Um Seculo de Transformacoes. Sao Paulo: Companhia das Letras. 